\title{
Metal hydride technologies for renewable energy
}

\author{
Alexey Kazakov ${ }^{1 *}$, Dmitry Blinov ${ }^{1,2}$, Ivan Romanov $^{1}$, Dmitry Dunikov ${ }^{1,2}$ and Vasily Borzenko ${ }^{1}$ \\ ${ }^{1}$ Joint institute for high temperatures RAS, Krasnokazarmennaya str. 17a, Moscow, Russia \\ ${ }^{2}$ National Research University "Moscow Power Engineering Institute" Krasnokazarmennaya str. 14, Russia
}

\begin{abstract}
Significant progress in the installation of renewable energy requires the improvement of energy production and storage technologies. Hydrogen energy storage systems based on reversible metal hydride materials can be used as an energy backup system. Metal hydride hydrogen storage systems are distinguished by a high degree of safety of their use, since hydrogen is stored in a solid phase, a high volumetric density of stored hydrogen, and the possibility of long-term storage without losses. A distinctive feature of metal hydride materials is the reversible and selective absorption and release of high-purity hydrogen. This paper presents experimental studies of LaNis-based metal hydride materials with a useful hydrogen capacity of 1.0-1.3 wt.\% $\mathrm{H}_{2}$ with equilibrium pressures of $0.025-0.05 \mathrm{MPa}$ and $0.1-1.2 \mathrm{MPa}$ at moderate temperatures of $295-353$ $\mathrm{K}$ for the hydrogen purification systems and hydrogen long-term storage systems, respectively. The applicability of metal hydride technologies for renewable energy sources as energy storage systems in the form of hydrogen is also shown.
\end{abstract}

\section{Introduction}

In recent years, there is a steady increase of installed capacity based on renewable energy resources. Renewable power accounted for $70 \%$ of net additions to global power generating capacity in 2017, the largest increase in renewable power capacity in modern history. The average growth rate of modern renewable energy technologies in the last decade has reached 5.4\%. Solar PV additions were up to $29 \%$ relative to 2016 , to $98 \mathrm{GW}$. More solar PV generating capacity was added to the electricity system than net capacity additions of coal, natural gas and nuclear power combined. Wind power also drove the uptake of renewables with $52 \mathrm{GW}$ added globally [1]. A reduction of traditional hydrocarbon energy carriers' consumption, development and installation of energy-saving technologies, increase of electricity production based on renewable energy sources contributes to improving the environmental situation in the world, rational use of energy resources and decentralization of energy supply.

The Russia's long-term energy strategy provide for the development of new renewable energy technologies, as well as bioenergy technologies [2]. Renewable energy sector is an important part of sustainable energy development of Russia, since about $2 / 3$ of the Russia's territory with population about 20 million is not covered by Unified Energy System [3]. The use of expensive imported fossil fuels in power plants with internal combustion engines is characterized by low efficiency and causes significant harm to the environment. Distributed renewable energy solutions, such as photovoltaic plants, small wind farms, biomass plants and micro hydropower plants, can provide electricity to remote areas or suffer from unstable power supply. Research and development of efficient autonomous power supply systems using locally available renewable energy sources is highly relevant. In addition, combination of such systems with energy storage in hydrogen - a universal and environmentally friendly secondary energy carrier, can improve overall system efficiency.

One of the main obstacles for the development of renewable based autonomous power plants for remote regions is the inconsistency of energy supply and consumption schedules. The uneven nature of operation modes for wind and solar power plants requires the creation of an energy storage system that will satisfy the needs of the consumer according to the load schedule he needs. Hydrogen energy storage systems can be a promising solution [4-7]. According to power plants based on wind or sun renewable energy sources, energy transformation can be shown as hydrogen production by electrolysis from renewable energy, hydrogen storage in a compressed or solid-state form and power generation by fuel cells or hydrogen combustion plants (including internal combustion engines) [4, 8]. Another promising solution is biological hydrogen production from local biomass, its purification and end-use in fuel cell to produce energy [9-11].

Among different technologies of hydrogen purification and storage, those ones based on metal hydride hydrogen storage systems, utilizing selective and reversible hydrogen uptake and release, can become economically feasible $[12,13]$. In this case, hydrogen stored in solid state inside the metal hydride bed, what provides enhanced safety during operation. Present work is related to experimental investigations of several metal

kazakoffalex09@gmail.com 
hydride materials and their implementation to hydrogen purification and storage systems.

\section{Metal hydride technologies}

Hydrogen storage by metal hydrides comprises an intermetallic alloy phase that has the capability to absorb and store atomic hydrogen in interstitial sites of metal lattice. Metal hydrides represent an exciting process of hydrogen storage, which is inherently safer than the compressed gas or liquid hydrogen storage. The typical interaction of metal hydrides with hydrogen can be expressed by following equation:

$$
M+\frac{x}{2} H_{2} \leftrightarrow M H_{x}+\Delta H
$$

where $\mathrm{M}$ is metal/intermetallic alloy, $\mathrm{H}$ is hydrogen.

The interaction of metal and hydrogen can be divided into three regions [14]: a dissolution of hydrogen in the metal matrix forming solid solution ( $\alpha$ phase); a coexistence of the hydrogen solid solution and hydride $(\alpha$ $+\beta$ phase); hydrogen dissolution in hydride ( $\beta$-phase) (Fig. 1).
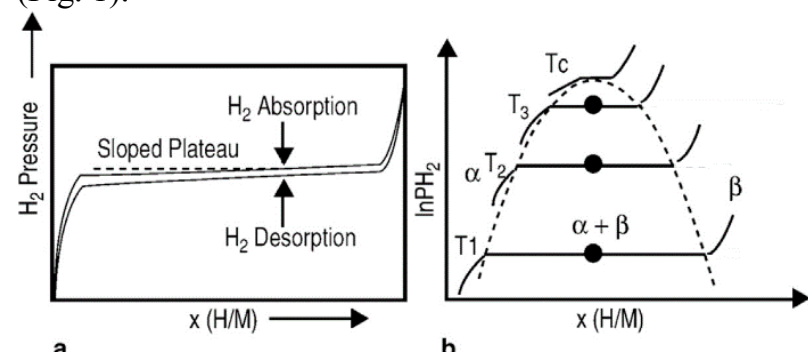

Fig.1. a) Sorption-desorption isotherm with plateau slope and hysteresis; b) idealized PCT diagram of «metal - hydrogen» system, adapted from [15].

During the formation of the metal hydride, hydrogen molecules are dissociated into hydrogen atoms on the metal surface, which insert themselves into interstitial spaces inside the lattice of intermetallic compounds and/or alloys. The effect is reversible and the direction is determined by the pressure (and temperature) of the hydrogen gas. If the pressure is above a certain level (the equilibrium pressure), the effect proceeds to the right to form hydride, whereas below the equilibrium pressure, hydrogen is liberated and the intermetallic matrix returns to its original state. The equilibrium pressure, itself, depends upon temperature. It increases due to expansion with an increment in temperature (and vice versa) [16]. The volume expansion between the coexisting $\alpha$ - and the $\beta$-phase corresponds in many cases $10-20 \%$ of the metal lattice. Therefore, at the phase boundary, large stresses are created that frequently lead to a decrepitation of brittle host metals including intermetallic compounds, resulting in a final hydride powder with a representative particle size of $1-10 \mu \mathrm{m}$.

The equilibrium pressure as a function of temperature is related to the changes of enthalpy $\Delta \mathrm{H}$ and entropy $\Delta \mathrm{S}$ by the Van't Hoff equation:

$$
\ln \left[\frac{P\left(H_{2}\right)}{P^{0}}\right]=\frac{\Delta H}{R T}-\frac{\Delta S}{R}
$$

where $\mathrm{P}\left(\mathrm{H}_{2}\right)$ is the hydrogen equilibrium pressure at $\alpha$ to $\beta$ hydride phase conversion; $\mathrm{P}^{0}$ is the standard pressure $(\mathrm{Pa}), \mathrm{R}$ is the ideal gas constant, and $\mathrm{T}$ is the absolute temperature $(\mathrm{K})$.

The reversible hydrides of intermetallic compounds are primarily considered as promising materials for the hydrogen storage and purification. The intermetallic compounds can be represented by the general formula $\mathrm{A}_{\mathrm{m}} \mathrm{B}_{\mathrm{n}} \mathrm{H}_{\mathrm{x}}$, where $\mathrm{A}$ is a hydride forming metal ( $\mathrm{La}, \mathrm{Ce}$, $\mathrm{Mm}, \mathrm{Ti}, \mathrm{Zr}, \mathrm{V}, \mathrm{Mg}$ ), and metal $\mathrm{B}$ does not interact with hydrogen under normal conditions ( $\mathrm{Ni}, \mathrm{Co}, \mathrm{Fe}, \mathrm{Mn}, \mathrm{Cr}$, $\mathrm{Al}$ and others). Depending on the metal A to metal B ratio, the IMCs can be classified in several basic types: $\mathrm{AB}_{5}$, $\mathrm{AB}_{2}, \mathrm{AB}_{3-3.5}, \mathrm{AB}, \mathrm{A}_{2} \mathrm{~B}, \mathrm{Ti}-\mathrm{V}, \mathrm{V}$-based solid solutions. These materials have a remarkable combination of properties, including selective hydrogen absorption from gaseous mixtures, reversibility of interaction with hydrogen, mild operating conditions, high volumetric density of hydrogen in the solid state. Main disadvantage is low gravimetric density, which does not exceed $1-2 \%$ wt., but it is not significant limitation for stationary applications $[12,17]$. To current date, there are a number of practical application of metal hydrides in hydrogen storage systems [18-21], hydrogen compression [22-28], hydrogen purification [29-31].

Major advantages of the $\mathrm{AB}_{5}$ type intermetallic compounds are the possibility of fine tuning of their operating conditions within moderate conditions at temperatures $273-373 \mathrm{~K}$ and pressures $0-1.0 \mathrm{MPa}$ with alternation of a compound composition. $\mathrm{AB}_{5}$ intermetallic compounds can be easily activated, do not form protective oxide films, which is an advantage that gives $\mathrm{AB}_{5}$ alloys an unusual resistance to small amounts of $\mathrm{O}_{2}$ and $\mathrm{H}_{2} \mathrm{O}$ in $\mathrm{H}_{2}$. These impurities do not poison $\mathrm{AB}_{5}$ alloys, only slightly lower the capacity. $\mathrm{CO}, \mathrm{H}_{2} \mathrm{~S}$ are a strong poisonous gases, but the recovery of the initial properties of the alloy can be achieved by heating $\left(100^{\circ} \mathrm{C}\right)$ and passing pure $\mathrm{H}_{2}$ through the alloy [17]. According to hydrogen production from renewables (wind, solar and biomass) most important properties for metal hydride storage system are low plateau pressure at near ambient conditions, cyclic stability and gas impurity resistance.

\section{Experimental investigations of $\mathrm{AB}_{5}$ intermetallic compounds}

Two series of $\mathrm{AB}_{5}$ alloys with low equilibrium pressures (LP alloys): $\quad \mathrm{LaNi}_{4.8} \mathrm{Fe}_{0.3} \mathrm{Mn}_{0.1}$, $\mathrm{LaNi}_{4.6} \mathrm{Al}_{0.2} \mathrm{Mn}_{0.2}, \quad \mathrm{LaNi}_{4.8} \mathrm{Al}_{0.2}$ and high equilibrium pressures (HP alloys): $\quad \mathrm{La}_{0.9} \mathrm{Ce}_{0.1} \mathrm{Ni}_{5}, \quad \mathrm{La}_{0.7} \mathrm{Ce}_{0.3} \mathrm{Ni}_{5}$, $\mathrm{MmNi}_{4.15} \mathrm{Fe}_{0.85}$ for different purposes were prepared by argon arc melting [32]. Low-pressure alloys are suitable for hydrogen purification from biologically produced gas. In addition, high-pressure alloys are perspective for longterm hydrogen storage produced from renewables by electrolysis.

$\mathrm{X}$-ray diffraction measurements of $\mathrm{AB}_{5}$ alloys have shown high homogeneity of the samples, XRD diagrams confirm that the structure of the samples belong to $\mathrm{CaCu}_{5}$ type. PCT curves are measured in 295 - $333 \mathrm{~K}$ temperature range for all samples. PCT curves of both low-pressure and high-pressure alloys at $295 \mathrm{~K}$ are shown in Fig. 2, 3. 


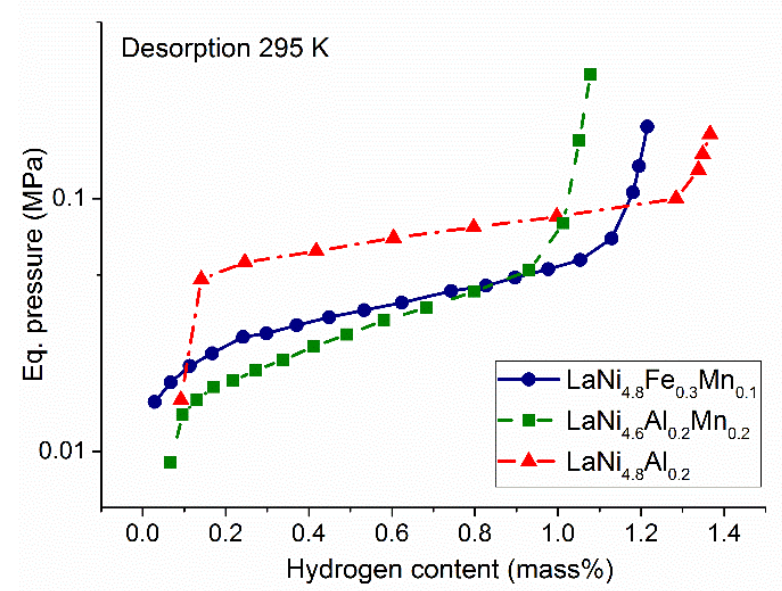

Fig. 2. Hydrogen desorption PCT isotherms for $\mathrm{AB}_{5} \mathrm{LP}$ alloys

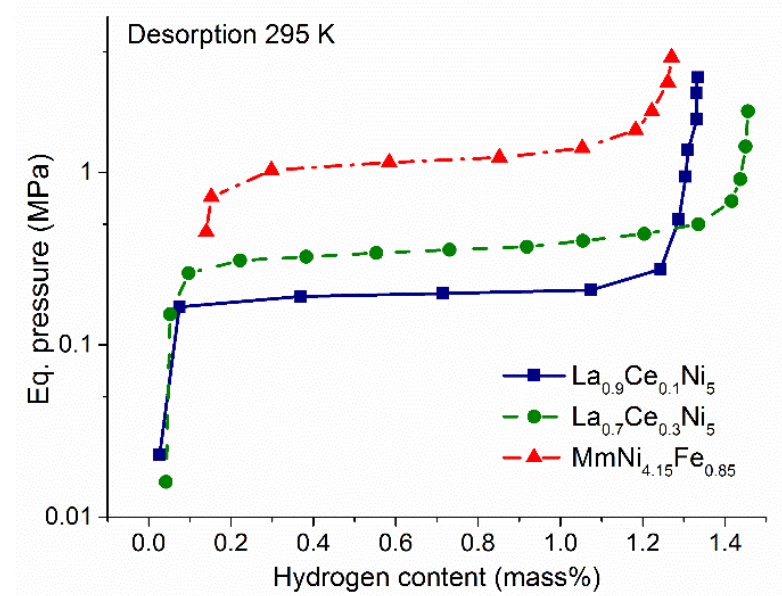

Fig. 3. Hydrogen desorption $\mathrm{PCT}$ isotherms for $\mathrm{AB}_{5} \mathrm{HP}$ alloys

Partial substitution of Ni by Al, Mn, Fe significantly reduce hydrogen equilibrium pressure in comparison with original LaNi 5 . Bigger atoms of Al, Mn, Fe enlarge crystal unit cell parameters leading to increase of interstitial holes in crystal structure. Highest reversible capacity is measured $1.2 \%$ wt. for $\mathrm{LaNi}_{4.8} \mathrm{Al}_{0.2}$, but hydrogen equilibrium pressure is too high for use in biohydrogen purification. $\mathrm{LaNi}_{4.8} \mathrm{Fe}_{0.3} \mathrm{Mn}_{0.1}$ alloy shows appropriate properties at near ambient conditions.

On the other hand, partial substitution of La by Ce or use of mixture of rare earth metals named as "mishmetal" $\mathrm{Mm}$ increases hydrogen equilibrium pressure. This effect appears because of decrease of crystal unit cell for Cesubstituted alloys. The particular behavior of Cesubsituted alloys has been attributed to the intermediate valence state of $\mathrm{Ce}\left(\mathrm{Ce}^{3+}, \mathrm{Ce}^{4+}\right)$ [33]. Two alloys $\mathrm{La}_{0.9} \mathrm{Ce}_{0.1} \mathrm{Ni}_{5}$ and $\mathrm{La}_{0.7} \mathrm{Ce}_{0.3} \mathrm{Ni}_{5}$ have suitable equilibrium pressures and hydrogen capacities for long-term hydrogen storage application.

Results of the thermodynamic measurements are listed in Table 1. Low pressure intermetallic compounds tend to form more stable hydrides than high pressure ones. On the other hand, high pressure intermetallic compounds have larger reversible hydrogen capacity at the same conditions.
Table 1 Thermodynamic parameters of $\mathrm{AB}_{5}$ type intermetallic compounds

\begin{tabular}{|c|c|c|c|c|}
\hline MH alloy & $\begin{array}{l}P_{d e s} \\
295 \\
\mathrm{MPa}\end{array}$ & $\begin{array}{c}C_{\text {rev }} \\
295 \text {, } \\
\text { wt. \% }\end{array}$ & $\begin{array}{l}\Delta \mathrm{H}_{\mathrm{des}}, \\
\mathrm{kJ} / \mathrm{mol}\end{array}$ & $\begin{array}{c}\Delta S_{d e s}, \\
\mathrm{~kJ} / \mathrm{mol} \\
\mathrm{K}\end{array}$ \\
\hline \multicolumn{5}{|c|}{ Low pressure alloys } \\
\hline $\mathrm{LaNi}_{4.8} \mathrm{Fe}_{0.3} \mathrm{Mn}_{0.1}$ & 0.049 & 1.0 & -36.8 & 119.7 \\
\hline $\mathrm{LaNi}_{4.6} \mathrm{Al}_{0.2} \mathrm{Mn}_{0.2}$ & 0.033 & 0.9 & -35.0 & 107.2 \\
\hline $\mathrm{LaNi}_{4.8} \mathrm{Al}_{0.2}$ & 0.074 & 1.2 & -35.5 & 116.9 \\
\hline \multicolumn{5}{|c|}{ High pressure alloys } \\
\hline $\mathrm{La}_{0.9} \mathrm{Ce}_{0.1} \mathrm{Ni}_{5}$ & 0.19 & 1.1 & -31.2 & 112.1 \\
\hline $\mathrm{La}_{0.7} \mathrm{Ce}_{0.3} \mathrm{Ni}_{5}$ & 0.36 & 1.3 & -33.1 & 123.0 \\
\hline $\mathrm{La}_{0.36} \mathrm{Ce}_{0.64} \mathrm{Ni}_{4.15} \mathrm{Fe}_{0.85}$ & 1.18 & 1.1 & -28.3 & 115.8 \\
\hline
\end{tabular}

\section{Metal hydride system for hydrogen purification}

The separation and purification of hydrogen using metal hydrides is based on the selective hydrogen absorption by hydrogen storage materials. Metal hydride hydrogen separation system can be a promising solution for smallscale power generating devices based on biologically produced hydrogen. Hydrogen extraction from liquid phase during anaerobic fermentation by different types of metal hydrides is investigated in [34]. Miura et al. [35-37] presented $100 \mathrm{Nl} / \mathrm{h}$ lab scale and $3 \mathrm{Nm}^{3} / \mathrm{h}$ bench scale systems based on metal hydrides for hydrogen extraction from reforming gas. Surface modification (fluorination, electroless deposition, etc.) of metal hydrides was applied to improve poisoning tolerance against $\mathrm{CO}$ and $\mathrm{CO}_{2}[30$, $31,38-40]$. Our research team [41] showed practical applicability of metal hydride technology for biohydrogen separation from different gas compositions. Separation of hydrogen by flow-through technique was applied in tubular metal hydride reactor with external and internal heat exchangers. $\mathrm{LP}$ alloy $\mathrm{LaNi}_{4.8} \mathrm{Fe}_{0.3} \mathrm{Mn}_{0.1}$ and $\mathrm{HP}$ alloy $\mathrm{La}_{0.9} \mathrm{Ce}_{0.1} \mathrm{Ni}_{5}$ are experimentally investigated in in tubular metal hydride reactor RSP-8 (Fig.4) with external and internal heat exchangers for continuous hydrogen purification and storage. Metal hydride powder is in the annular gap as a thin layer between two heat exchangers to enhance thermal conductivity and increase overall purification efficiency. For LP alloy the purification rate of $81 \mathrm{st} . \mathrm{L} / \mathrm{h}$ from a mixture containing $59 \mathrm{vol} . \%$ of hydrogen with recovery $94 \%$ was achieved. HP alloy shows lower purification efficiency compared with LP alloy because of a small pressure gap between inlet hydrogen pressure and equilibrium pressure of the alloy. On the other hand, HP alloy can release hydrogen for fuel cell supply without any additional heating.

Two reactors RSP -8 are integrated to lab scale power generation system "H2Biopower" as hydrogen purification and storage unit. HP alloy $\mathrm{La}_{0.9} \mathrm{Ce}_{0.1} \mathrm{Ni}_{5}$ is used to supply PEM fuel cell at required pressure. 


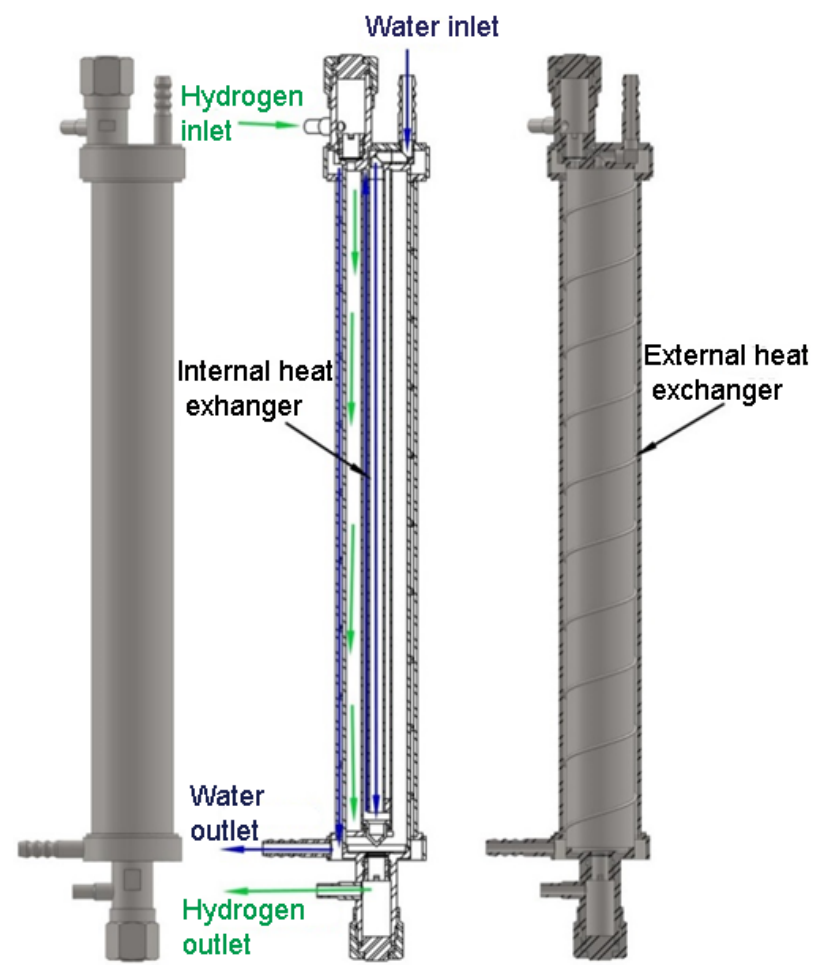

Fig. 4. Metal hydride hydrogen storage and purification reactor RSP-8.

The "H2Biopower" system includes the following main parts (Fig.5):

1. Tank of modelled biohydrogen (gas mixture of hydrogen $50 \%$ vol. and carbon dioxide 50\% vol.);

2. Metal hydride hydrogen purification and storage system based on two reactors RSP-8 developed by JIHT RAS (working hydrogen capacity of each metal hydride reactor is $110 \mathrm{Nl} \mathrm{H}_{2}$ );

3. Power plant based on fuel cell Hoppecke E-200, power $200 \mathrm{~W}$; PXI.

4. Automated Data Acquisition System based on NI

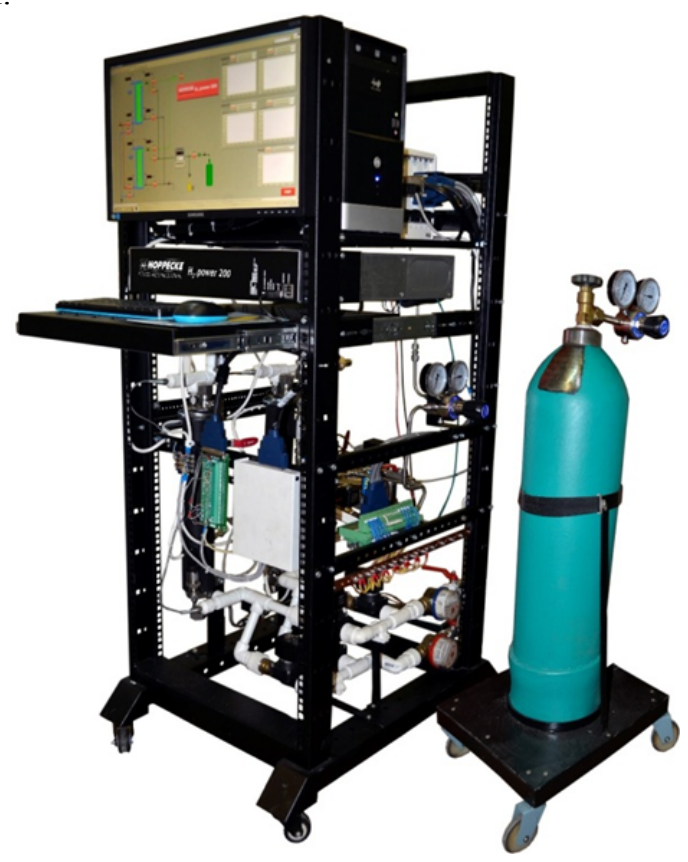

Fig. 5. Front view of lab-scale power generation system "H2Biopower"

At test run, firstly hydrogen is charged from pure hydrogen source. The total amount of stored hydrogen is $110 \mathrm{Nl}$ by one RSP-8 metal hydride reactor. To provide require pressure for fuel cell supply metal hydride reactor is heated stepwise by tap hot water with temperature $318-328$ K (Fig.6). Pressure drastically drops at constant temperature at the end of discharge, that means release of all stored hydrogen from metal hydride bed. Hydrogen volume stored in RSP-8 is enough for fuel cell operation during approximately $45 \mathrm{~min}$. Operation characteristics of fuel cell Hoppecke-200 are shown in Fig.7.

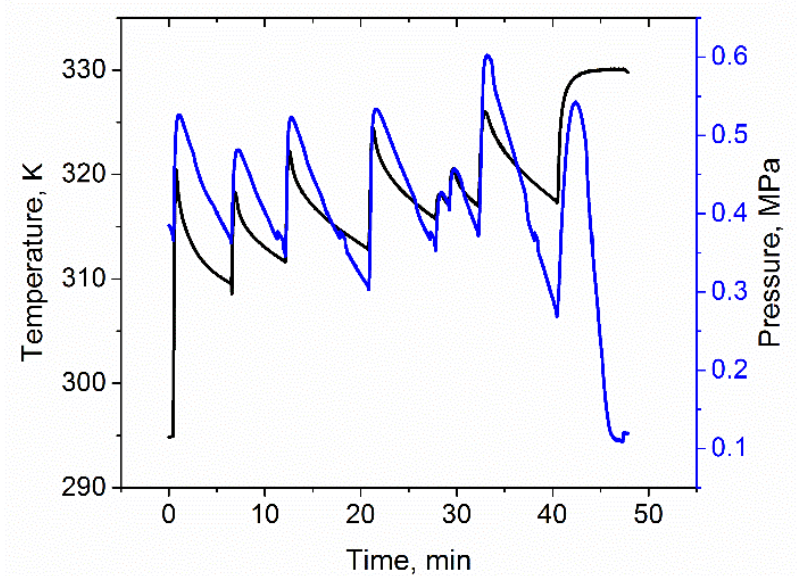

Fig. 6. Temperature of heat exchange fluid and outlet hydrogen pressure of RSP-8 metal hydride reactor during discharge.

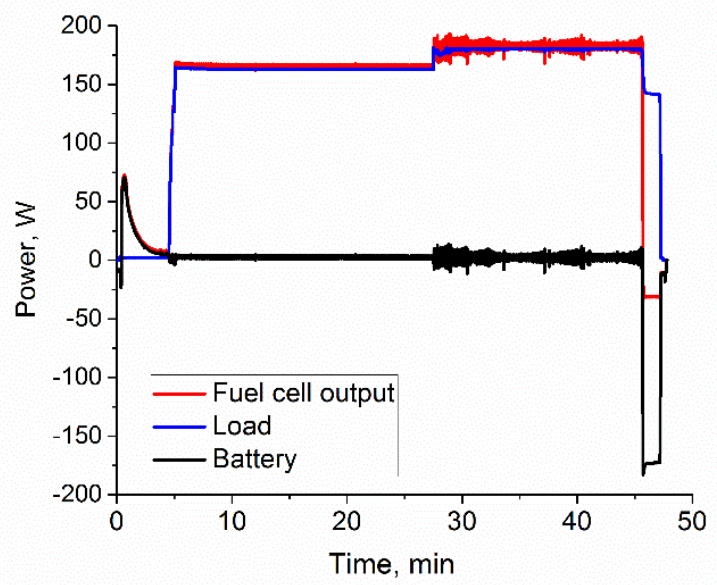

Fig. 7. Temperature of heat exchange fluid and outlet hydrogen pressure of RSP-8 metal hydride reactor during discharge.

For continuous operation, a battery is provided that is connected to fuel cell in parallel. At the beginning of fuel cell operation, the battery is charged from the fuel cell. Then the required electric power is delivered to the consumer. Fuel cell operates at a load of $163 \mathrm{~W}$ for 23 minutes. and at a load of $181 \mathrm{~W}$ and $18 \mathrm{~min}$.

The demonstration lab scale power generation system "H2Biopower" shows practical applicability to integrate different pathways for hydrogen production such as dark fermentation through its purification and storage by metal hydrides and end-use in fuel cells. However, metal hydrides with low equilibrium pressures are necessary for direct hydrogen extraction because hydrogen partial pressure does not exceed $0.04-0.06 \mathrm{MPa}$ in produced 
biogas [42, 43].

\section{Metal hydride system for stationary hydrogen storage}

Metal hydrides are known as a potential efficient, low-risk high-density hydrogen storage materials since the late 1970s [17, 44-46]. The use of metal hydride materials is characterized by compactness, safety, simplicity and flexibility. Application of metal hydrides can provide high volumetric hydrogen storage capacity, safety and reliability, high purity of the supplied $\mathrm{H}_{2}$. Lower pressure of stored hydrogen and limited rate of hydrogen release improves operational safety in the case of accidental leaks or even rupture of the hydrogen storage containment.

In order to achieve a good performance, the metal hydride reactor must be properly designed. However, the coupling process of porous flow, heat and mass transfer, and reaction kinetics in the reactor are highly transient and complicated, and many issues have to be taken into account in a realistic reactor scheme [47].

Several types of reactor design are proposed by laboratory of hydrogen energy technologies [41, 48, 49] The design of the metal hydride reactor RS- 1 is most suitable for long term stationary hydrogen storage. The reactor is stainless steel tube type heat exchanger with inner channels for liquid heating and metal hydride placed in the annular gap between the channel for liquid and the outer wall of each tube (Fig. 8). The reactor consists of 49 tubes with length of $65 \mathrm{~cm}$ united by common hydrogen collector. Each tube has stainless steel mesh filter at the inlet to retain metal hydride inside the tube.Total weight of $\mathrm{La}_{0.9} \mathrm{Ce}_{0.1} \mathrm{Ni}_{5}$ metal hydride is $81 \mathrm{~kg}$ at $70 \%$ fill of each tube.

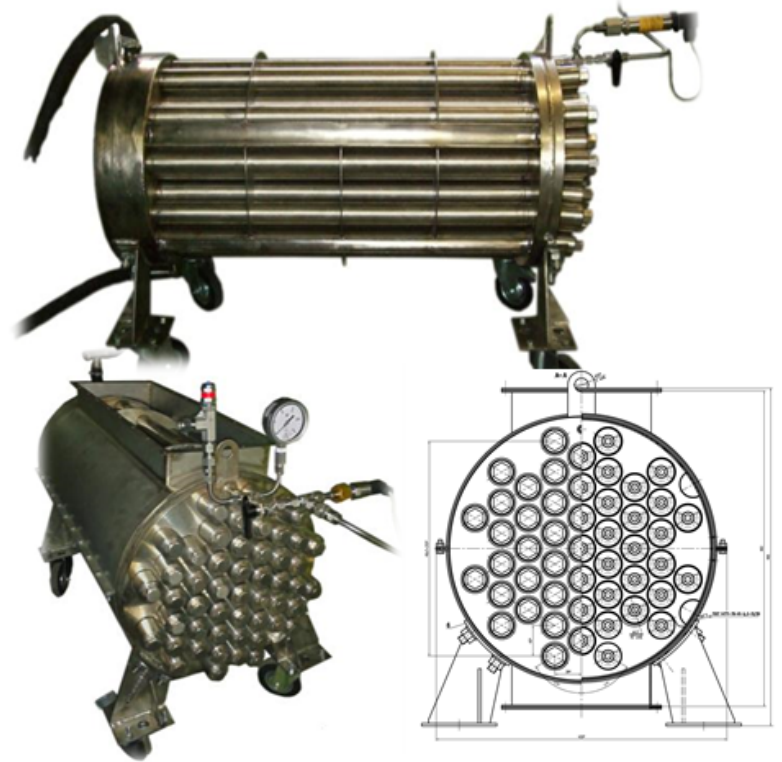

Fig. 8. Metal hydride hydrogen storage reactor RS-1: general view and frontal section.

Maximum capacity of RS-1 reactor is $12 \mathrm{Nm}^{3} \mathrm{H}_{2}$, which indicates full charge of metal hydride powder bed. Nominal capacity is $10 \mathrm{Nm}^{3} \mathrm{H}_{2}$. Ce-substituted $\mathrm{La}_{0.9} \mathrm{Ce}_{0.1} \mathrm{Ni}_{5}$ intermetallic compound is used as hydrogen storage material. Solid state hydrogen storage system in an explosion proof design for backup power supply is developed based on RS-1 metal hydride reactors (Fig.9). Technical characteristics are presented in Table 2 .

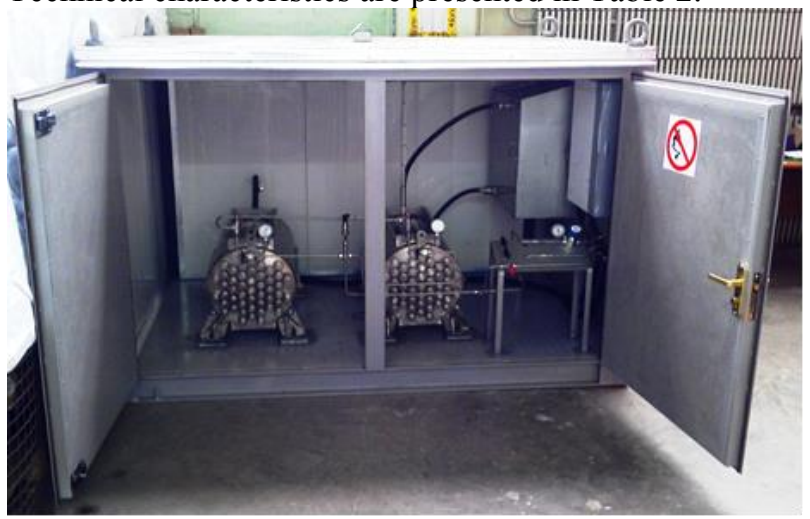

Fig.9. Long-term stationary metal hydride hydrogen storage system for backup power supply.

Table 2 Thermodynamic parameters of $\mathrm{AB}_{5}$ type intermetallic compounds

\begin{tabular}{|c|c|}
\hline \multicolumn{2}{|l|}{ Technical characteristics } \\
\hline Hydrogen flow rate, $\mathrm{Nm}^{3} / \mathrm{h}$ & 10 \\
\hline Hydrogen purity at inlet, $\%$ vol. & 99.95 \\
\hline Hydrogen capacity, $\mathrm{Nm}^{3}$ & 20 \\
\hline Hydrogen purity at outlet, \%vol. & 99.9995 \\
\hline Working hydrogen pressure, $\mathrm{MPa}$ & 0.4 \\
\hline Heat transfer fluid temperature, ${ }^{\circ} \mathrm{C}$ & $0 \div 95$ \\
\hline Heat transfer fluid flow rate, $\mathrm{Nm}^{3} / \mathrm{h}$ & $0.8 \div 2$ \\
\hline Power consumption, $\mathrm{kW}$ & 0.3 \\
\hline $\begin{array}{l}\text { Thermal energy consumption rate at } \\
\text { reactor charge, } \mathrm{kW}\end{array}$ & 6 \\
\hline
\end{tabular}

\section{Conclusions}

Hydrogen energy storage systems based on reversible metal hydride materials show their perspectives in implementation with rapidly growing renewable energy production technologies. $\mathrm{AB}_{5}$ type intermetallic compounds have many advantages such as easy activation, impurity tolerance, mild operating conditions, high volumetric density of hydrogen in the solid state and variety of compositions to meet the requirements for practical application in different fields.

$\mathrm{LaNi}_{5}$ based intermetallic compounds substituted by $\mathrm{Ce}, \mathrm{Al}, \mathrm{Mn}, \mathrm{Fe}$ are prepared and investigated for different purposes. Reversible hydrogen capacities reach $1.1-1.3 \%$ wt. and hydrogen equilibrium pressures are in a wide range from 0.033 to $1.18 \mathrm{MPa}$ for investigated alloys.

The demonstration lab scale power generation system "H2Biopower" is developed including two RSP-8 metal hydride reactors as a hydrogen separation system. One fully charged RSP-8 metal hydride reactor is able to supply fuel cell during 45 minutes to produce electric 
energy. practical applicability to integrate different pathways for hydrogen production such as dark fermentation through its purification and storage by metal hydrides and end-use in fuel cells is shown.

Long-term hydrogen storage system with capacity $20 \mathrm{Nm}^{3} \mathrm{H}_{2}$ based on RS-1 metal hydride reactor filled with $\mathrm{La}_{0.9} \mathrm{Ce}_{0.1} \mathrm{Ni}_{5}$ intermetallic compound for backup power supply is presented.

\section{References}

1. REN21, RENEWABLES 2018 GLOBAL STATUS REPORT. 2018: Paris.

2. Rossijskaya Federaciya. Energeticheskaya strategiya Rossii na period do 2030 goda. 2009.

3. Dunikov, D.O., Russia's view on development of novel and renewable energy sources, including hydrogen energy. International Journal of Hydrogen Energy, 2015. 40(4): p. 2062-2063.

4. Zoulias, E.I. and N. Lymberopoulos, Hydrogen-based autonomous power systems: techno-economic analysis of the integration of hydrogen in autonomous power systems. 2008: Springer.

5. Hydrogen and Fuel Cells: Fundamentals, Technologies and Applications. 2010, Weinheim, Germany: WILEY-VCH Verlag GmbH. 877.

6. Malyshenko S.P. Vodorod kak akkumulyator energii v elektroenergetike. Rossiyskiy khimicheskiy zhurnal, 2005. XLI: p. 112-120.

7. da Rosa, A, Vozobnovlyaemiye istochniki energii. Fiziko-tekhnicheskie osnovy : uchebnoe posobie. 2010, M.: Izdatelskiy dom MEI. 704.

8. Tzamalis, G., et al., Techno-economic analysis of an autonomous power system integrating hydrogen technology as energy storage medium. Renewable Energy, 2011. 36(1): p. 118-124.

9. Kim, D.-H., et al., Experience of a pilot-scale hydrogen-producing anaerobic sequencing batch reactor (ASBR) treating food waste. International Journal of Hydrogen Energy, 2010. 35(4): p. 1590-1594.

10. La Licata, B., et al., Bio-hydrogen production from organic wastes in a pilot plant reactor and its use in a SOFC. International Journal of Hydrogen Energy, 2011. 36(13): p. 7861-7865.

11. Morra, S., et al., Expression of different types of [FeFe]-hydrogenase genes in bacteria isolated from a population of a bio-hydrogen pilot-scale plant. International Journal of Hydrogen Energy, 2014. 39(17): p. 9018-9027.

12. Malyshenko S.P. Nazarova O.V., Akkumulirovanie vodoroda, Atomno-vodorodnaya energetika $i$ tekhnologiya. Vol. 8. 1988, Energoatomizdat: M. p. 155. 13. Verbetsky, V.N., et al., Metal hydrides: properties and practical applications. Review of the works in CIScountries. International Journal of Hydrogen Energy, 1998. 23(12): p. 1165-1177.

14. Kolachev B.A., Shalin R.E., Ilyin A.A., Splavynakopiteli vodoroda. 1995, M.: Metallurgiya. 384.

15. Tarasov B.P., et al., Metody khraneniya vodoroda $i$ vozmozhnosti ispol'zovaniya metallogidridov.
Al'ternativnaya energetika i ekologiya, 2005. 12: p. 1437.

16. Srinivasan, S.S. and D.E. Demirocak, Metal Hydrides used for Hydrogen Storage, in Nanostructured Materials for Next-Generation Energy Storage and Conversion: Hydrogen Production, Storage, and Utilization, Y.-P. Chen, S. Bashir, and J.L. Liu, Editors. 2017, Springer Berlin Heidelberg: Berlin, Heidelberg. p. 225-255.

17. Sandrock, G., A panoramic overview of hydrogen storage alloys from a gas reaction point of view. Journal of Alloys and Compounds, 1999. 293-295: p. 877-888.

18. Kubo, K., Y. Kawaharazaki, and H. Itoh, Development of large MH tank system for renewable energy storage. International Journal of Hydrogen Energy, 2017. 42(35): p. 22475-22479.

19. Lototskyy, M., et al., Metal hydride hydrogen storage tank for fuel cell utility vehicles. International Journal of Hydrogen Energy, 2019.

20. Rabienataj Darzi, A.A., et al., Absorption and desorption of hydrogen in long metal hydride tank equipped with phase change material jacket. International Journal of Hydrogen Energy, 2016. 41(22): p. 9595-9610. 21. Capurso, G., et al., Development of a modular roomtemperature hydride storage system for vehicular applications. Applied Physics A, 2016. 122(3): p. 236.

22. Yartys, V.A., et al., Metal hydride hydrogen compression: recent advances and future prospects. Applied Physics A, 2016. 122(4): p. 415.

23. Lototskyy, M.V., et al., Metal hydride hydrogen compressors: A review. International Journal of Hydrogen Energy, 2014. 39(11): p. 5818-5851.

24. Burheim, O.S., Chapter 5 - Thermomechanical Energy Storage, in Engineering Energy Storage, O.S. Burheim, Editor. 2017, Academic Press. p. 63-73.

25. Hu, X.-c., et al., A 38 MPa compressor based on metal hydrides. Journal of Shanghai Jiaotong University (Science), 2012. 17(1): p. 53-57.

26. Lototskyy, M., et al., Thermally Driven Metal Hydride Hydrogen Compressor for Medium-Scale Applications. Energy Procedia, 2012. 29(0): p. 347-356.

27. Tarasov, B.P., et al., Cycling stability of RNi5 $(R=L a$, $L a+C e)$ hydrides during the operation of metal hydride hydrogen compressor. International Journal of Hydrogen Energy, 2018. 43(9): p. 4415-4427.

28. Li, H., et al., A study on 70MPa metal hydride hydrogen compressor. Journal of Alloys and Compounds, 2010. 502(2): p. 503-507.

29. Chen, X.Y., et al., A Review on the Metal Hydride Based Hydrogen Purification and Separation Technology. Applied Mechanics and Materials, 2014. 448-453: p. 3027-3036.

30. Modibane, K.D., et al., Poisoning-tolerant metal hydride materials and their application for hydrogen separation from $\mathrm{CO} 2 / \mathrm{CO}$ containing gas mixtures. International Journal of Hydrogen Energy, 2013. 38(23): p. $9800-9810$.

31. Lototskyy, M., et al., Application of surface-modified metal hydrides for hydrogen separation from gas mixtures containing carbon dioxide and monoxide. Journal of Alloys and Compounds, 2013. 580, Supplement 1(0): p. S382-S385. 
32. Kazakov A.N., Dunikov D.O., Borzenko V.I., Razrabotka metodiki izgotovleniya $i$ issledovaniya obraztsov intermetallicheskikh soedineniy dlya sistem khraneniya i ochistki vodoroda. Vestnik MEI, 2014. 3: p. 16-20.

33. Senoh, H., et al., Systematic investigation on hydrogen storage properties of RNi5 (R: rare earth) intermetallic compounds with multi-plateau. Materials Science and Engineering: B, 2004. 108(1-2): p. 96-99.

34. Dimanta, I., et al., Metal hydride alloys for storing hydrogen produced by anaerobic bacterial fermentation. International Journal of Hydrogen Energy, 2016. 41(22): p. 9394-9401.

35. Miura, S., et al., A hydrogen purification and storage system using $C O$ adsorbent and metal hydride. Journal of Alloys and Compounds, 2013. 580, Supplement 1(0): p. S414-S417.

36. Miura, S., A. Fujisawa, and M. Ishida, A hydrogen purification and storage system using metal hydride. International Journal of Hydrogen Energy, 2012. 37(3): p. 2794-2799.

37. Miura, S., A hydrogen purification and storage system using metal hydride for DSS operations. 19th World Hydrogen Energy Conference 2012, 2012.

38. Lototsky, M.V., et al., Surface-modified advanced hydrogen storage alloys for hydrogen separation and purification. Journal of Alloys and Compounds, 2011. In Press, Corrected Proof.

39. Sun, Y.M. and S. Suda, Studies on the fluorination method for improving surface properties and characteristics of AB5-types of hydrides. Journal of Alloys and Compounds, 2002. 330-332: p. 627-631.

40. Wang, X.L., K. Iwata, and S. Suda, Hydrogen purification using fluorinated LaNi4.7Al0.3 alloy. Journal of Alloys and Compounds, 1995. 231(1-2): p. 860-864. 41. Dunikov, D., et al., Biohydrogen purification using metal hydride technologies. International Journal of Hydrogen Energy, 2016. 41(46): p. 21787-21794.

42. Liu, C.-M., et al., Biohydrogen production from rice straw hydrolyzate in a continuously external circulating bioreactor. International Journal of Hydrogen Energy, 2014. 39(33): p. 19317-19322.

43. Liu, C.-M., et al., Biohydrogen production evaluation from rice straw hydrolysate by concentrated acid pretreatment in both batch and continuous systems. International Journal of Hydrogen Energy, 2013. 38(35): p. 15823-15829.

44. Sakintuna, B., F. Lamari-Darkrim, and M. Hirscher, Metal hydride materials for solid hydrogen storage: A review. International Journal of Hydrogen Energy, 2007. 32(9): p. 1121-1140.

45. Lynch, F.E., Metal hydride practical applications. Journal of the Less Common Metals, 1991. 172-174, Part 3(0): p. 943-958.

46. Huston, E.L. and G.D. Sandrock, Engineering properties of metal hydrides. Journal of the Less Common Metals, 1980. 74(2): p. 435-443.

47. Yang, F.S., et al., Design of the metal hydride reactors - A review on the key technical issues. International Journal of Hydrogen Energy, 2010. 35(8): p. 3832-3840. 48. Malyshenko, S.P., et al., Metal hydride technologies of hydrogen energy storage for independent power supply systems constructed on the basis of renewable sources of energy. Thermal Engineering, 2012. 59(6): p. 468-478. 49. Dunikov, D., V. Borzenko, and S. Malyshenko, Influence of impurities on hydrogen absorption in a metal hydride reactor. International Journal of Hydrogen Energy, 2012. 37(18): p. 13843-13848. 